\title{
Article
}

http://dx.doi.org/10.11646/phytotaxa.255.1.4

\section{New species of Anthurium (Araceae) from Chucantí Nature Reserve, eastern Panama}

\author{
ORLANDO O. ORTIZ ${ }^{*}$, RICCARDO M. BALDINI ${ }^{2}$, GUIDO BERGUIDO ${ }^{3} \&$ THOMAS B. CROAT ${ }^{4}$ \\ ${ }^{1}$ Herbario PMA \& Programa de Maestría en Ciencias Biológicas, Universidad de Panamá. Estafeta Universitaria, Panama City, \\ Panama \\ e-mail:ortizopma@gmail.com \\ ${ }^{2}$ Department of Biology \& Tropical Herbarium FT, University of Florence, Italy; Smithsonian Tropical Research Insitute, Panama, Fel- \\ lowship \\ ${ }^{3}$ Adopt a Panama Rainforest Association (ADOPTA). P.O. Box 0801-00051. Panama City, Panama \\ ${ }^{4}$ Missouri Botanical Garden. P.O. Box 299. St. Louis, MO 63166-0299, USA \\ *author for correspondence
}

\begin{abstract}
In the present paper we describe two new endemic species of Anthurium, discovered during field trips to study the Araceae flora of the Chucantí Nature Reserve (Reserva Natural Chucantí) located in the province of Darién, Panama. Anthurium annularum sp. nov., a member of section Xialophyllium, is principally characterized by its hemiepiphytic climbing habit, stems with ring-shaped nodes with short internodes alternating with much longer internodes, a yellow-green spadix and pale green globose berries which are nearly translucent toward the base. A. chucantiense sp. nov, a member of section Polyneurium, is characterized by its epiphytic habit, short internodes at stem apex, terete petioles, blades with obscure primary lateral veins, greenish to pale orange spadix and narrowly ovoid, and bluntly pointed red-orange berries.
\end{abstract}

Key words: Taxonomy, Flora of Panama, Darién, Xialophyllium, Polyneurium.

\section{Introduction}

Anthurium Schott (1829: 828) is a Neotropical genus characterized principally by having leaf blades with reticulated venation, dimerous perigoniate bisexual flowers, a usually persistent spathe, seeds with endosperm, and pollen usually forate (Mayo et al. 1997). This genus is represented by 905 described species, but it is estimated that there are about 1500 species (Boyce \& Croat 2012). In Panama, there are about 182 species described (Croat \& Ortiz unpubl. data). According to Correa et al. (2004), in Darién Province there are about 2638 species of vascular plants, including 121 species of Araceae with 28 endemic species, representing one of the groups of vascular plants with the highest endemism (ANCON 2010).

Darién Province, which is located in eastern Panama, has a rich biodiversity and a high level of endemism (Dinerstein et al. 1995). Chucantí (Fig. 1) is located on the border of eastern Panama Province and Darién Province on the eastern edge of Serranía de Majé (Majé Mountain Range), a nature reserve of 404 ha. Aizprúa (unpubl. data) states that the elevation of the area ranges from 600 to $1480 \mathrm{~m}$ with the most of the vegetation characteristic of a premontane cloud forest. According to classification of Holdridge et al. (1971) Chucantí Nature Reserve has Tropical wet forests and Premontane rain forests. On the other hand, according to the ecoregion classification system (Fund 2014), Chucanti is a part of the Eastern Panamanian montane forests ecoregion, characterized by precipitation that ranges between $3000-4000 \mathrm{~mm}$ annually and elevations between 500-1800 m. According to Croat (1986), the mountains near Tortí Arriba (eastern Panamá Province), including the Serranía de Majé and the Serranía de Cañazas are centers of endemism of Anthurium and remain a underexplored area.

Recent exploration of the forests of the Serrania de Majé, specifically in the area of Chucantí, have revealed the presence of new species of plants and animals (Dressler 2003, Miranda \& Bermúdez 2010, Bezark et al. 2013, Batista et al. 2014). An unpublished preliminary study on the flora of Chucantí mentions that the Reserve includes more than 500 species of vascular plants (Ibáñez \& Flores unpubl. data). Fieldwork in Chucantí by the first and third 


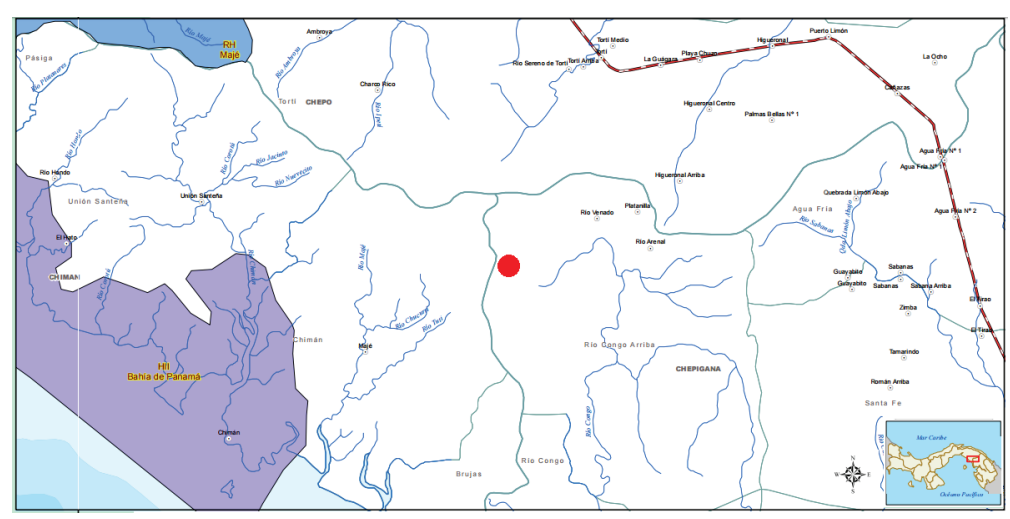

FIGURE 1. Location of the Chucantí Nature Reserve within Serranía de Majé, between Panama and Darien Province.

authors revealed the presence of poorly known and sparsely collected aroid species with restricted distribution such as: Anthurium collinsii Croat (1986: 59), A. tacarcunense Croat (1986: 186), Philodendron lazorii Croat (1997: 476), P. annulatum Croat (1997: 400) and Xanthosoma caladioides Grayum (1986: 471). At present, the areas near the Chucantí Nature Reserve are severely under threat by agricultural and livestock activities (Dinerstein et al. 1995, Laurance 2008, Fund 2014). It is essential to continue protecting the forests of Chucantí owing to their high species diversity, rates of endemism and, although some new plant and animal species have been described from this site, as noted the area is still poorly understood.

Here we describe two new species of Anthurium endemic to the Chucantí Nature Reserve (Reserva Natural Chucantí).

\section{Materials and methods}

The descriptions are of fertile material and all new species were keyed out with the Lucid Anthurium Key (Haigh et al. 2009). The descriptive terminology is according to Croat \& Bunting (1979).

\section{Taxonomy}

Anthurium annularum O.Ortiz, Croat \& Baldini, sp. nov. (Figs. 2, 3)

Anthurium annularum is characterized by its hemiepiphytic climbing habit, swollen ring-shaped nodes separated internodes of alternating lengths, long and short, cataphylls persisting intact at apex, later deciduous with a few fibrous remnants at the nodes, short (0.9-2.0 $\mathrm{cm}$ long) terete petioles, lanceolate-elliptic or narrowly elliptic yellow-brown drying leaf blades, a cylindrical yellow-green spadix, pendent inflorescence and pale green globose berries.

Type:-PANAMÁ. Darién: Serranía de Majé, Reserva Privada Chucantí, cima del Cerro Chucantí, 1325 m, 847’45” N, 78²7’47” W, 30 Aug 2014, Orlando O. Ortiz, Rodolfo Flores, Adriel Sierra, Juvenal Batista, Yessenia Guadalupe, Calixto Rodríguez, Zabdy Samudio \& Zuleika Serracín 2450 (holotype, PMA!; isotypes, FT!, MO!, SCZ!, UCH!, US!).

Hemiepiphytic climbing herb; stems to $1 \mathrm{~m}$ long, drying yellow-brown, longitudinally ribbed, matte; internodes alternating between short internodes and much longer internodes, $0.3-7 \mathrm{~cm}$ long, 2-4 mm diam., with ring-shaped 


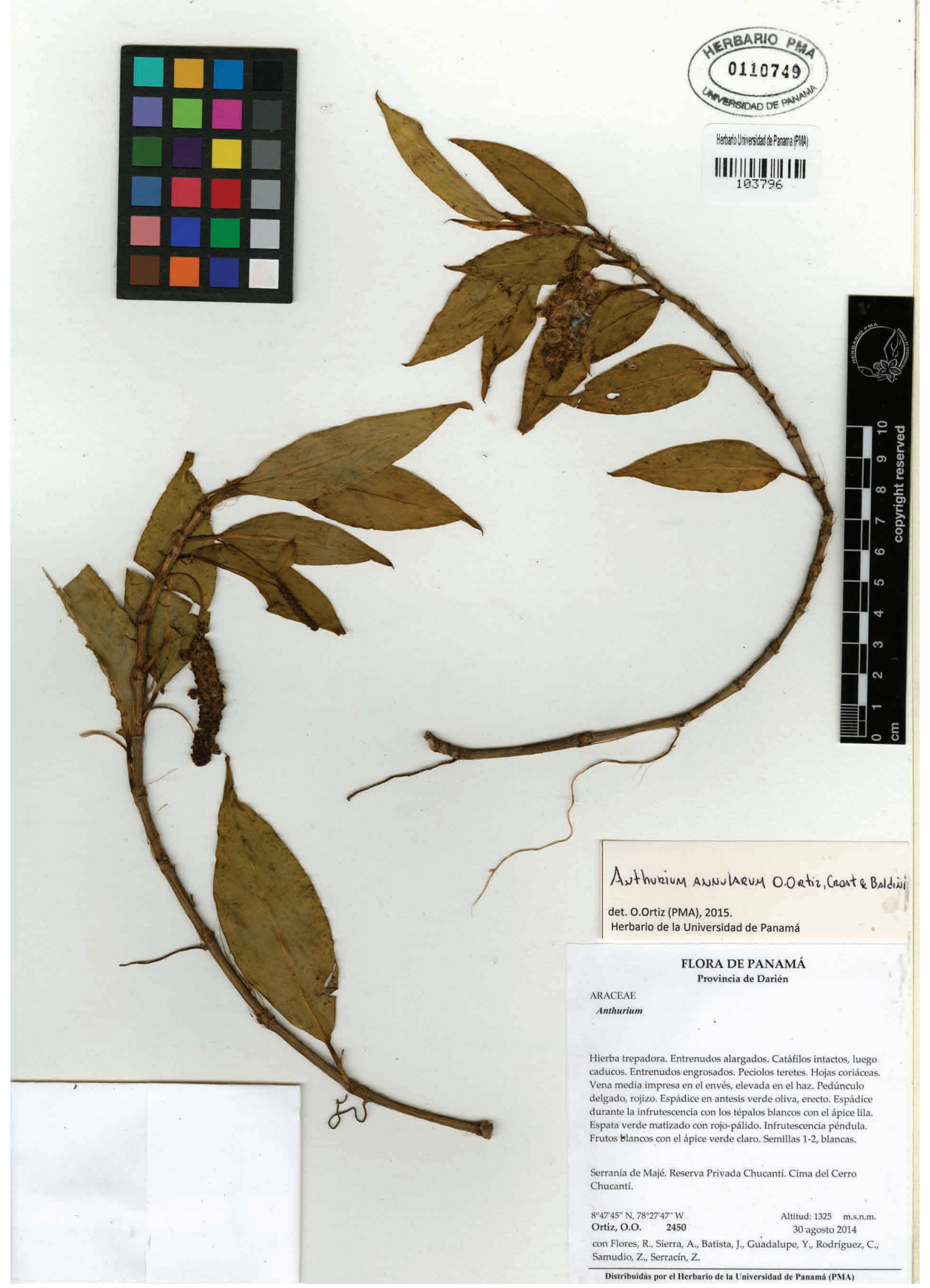

FIGURE 2. Anthurium annularum. Holotype specimen: Panamá. Darién: Serranía de Majé, Reserva Privada Chucantí, cima del Cerro Chucantí, 1325 m, 847’45” N, 78²7’47” W, 30 Aug 2014, Orlando O. Ortiz, Rodolfo Flores, Adriel Sierra, Juvenal Batista, Yessenia Guadalupe, Calixto Rodríguez, Zabdy Samudio \& Zuleika Serracín 2450 (Photo PMA Herbarium). 

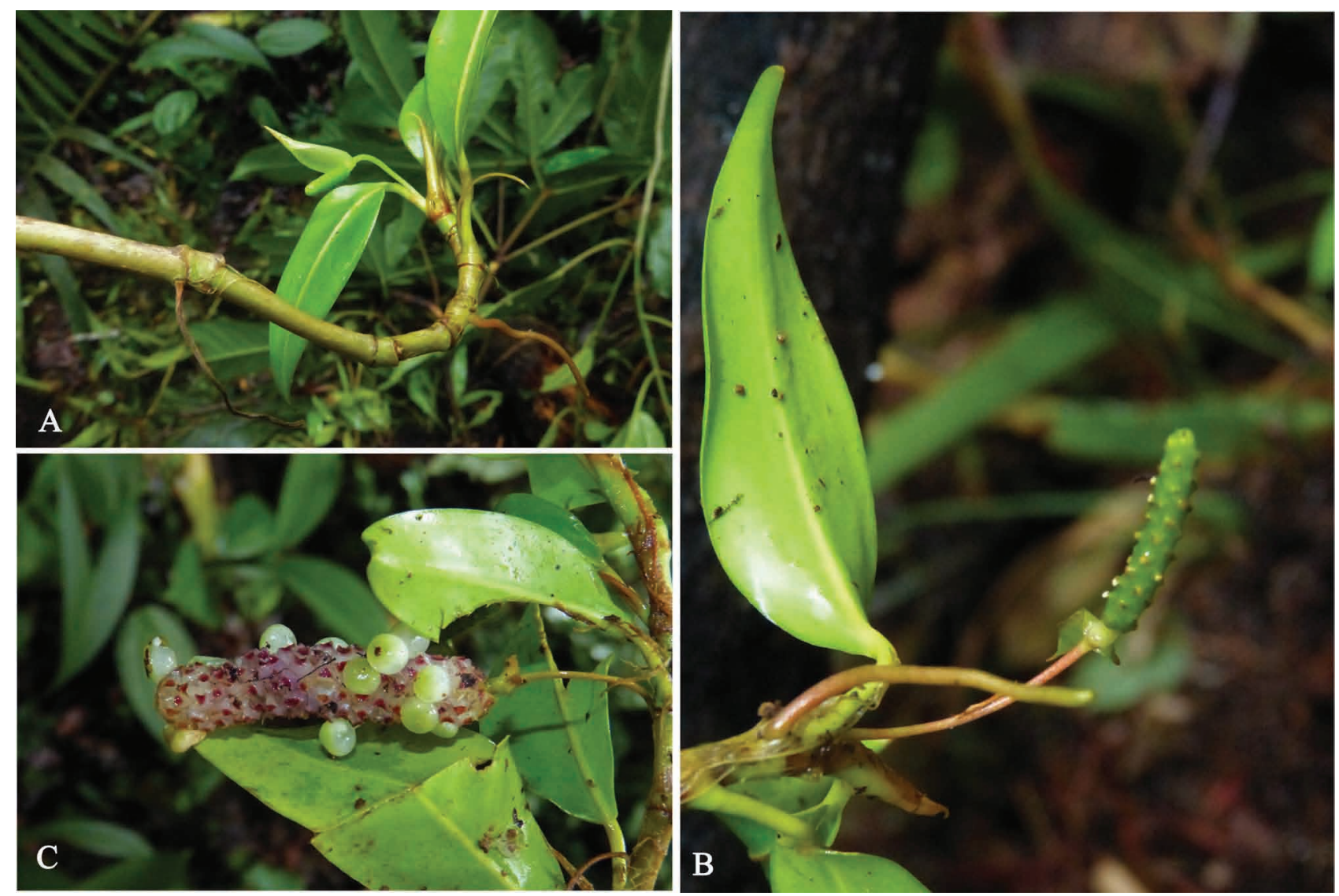

FIGURE 3. Anthurium annularum at the type locality. A. In its habitat. B. Flowering spadix. C. Infrutescence spadix (Photo Orlando O. Ortiz).

swellings at the apex of each internode; cataphylls persisting intact at apex, later deciduous with a few fibrous remnants at node, drying yellow-brown, 0.5-5 cm long; petioles terete, 0.9-2.0 cm long, $1.0 \mathrm{~mm}$ in diam., drying matte, dark brown on geniculum and at base; blades lanceolate-elliptic or narrowly elliptic, gradually acuminate at apex, acute at base, 5-10 × 1.4-3.3 cm, 2.4-3 times longer than broad, ca. 5 times longer than petioles, broadest slightly below the middle, subcoriaceous to moderately thin, medium green and semi-glossy above, slightly paler and semi-glossy below, drying yellow-brown; midrib narrowly rounded and slightly paler above, narrowly rounded below; primary lateral veins ca. 16 pairs, obscure on both surfaces when fresh, moderately obscure when dried, arising at $40-50^{\circ}$ angle; tertiary veins obscure. Inflorescence erect-spreading; peduncle 1.5-3.5 cm long, $1.0 \mathrm{~mm}$ in diam., slender, reddish; spathe reflexed-spreading (at anthesis) or erect, 1.1-1.5 $\times 0.4-0.6 \mathrm{~cm}$, whitish-green to green, ovate to narrowly lanceolate, abruptly acuminate at apex; spadix yellow-green, erect, cylindrical, $0.7-1.9 \mathrm{~cm}$ long, $1-2 \mathrm{~mm}$ in diam. on drying, 7-10 times longer than wide, stipitate ca. 1-2 mm when dried, stipe whitish; flowers 3-4 visible in the principal spiral, 2-3 in the alternate spiral; stamens slightly exserted; anthers whitish. Infructescence pendent; spathe deciduous; spadix cylindrical, 3.5-4.2 cm long, 1-1.3 cm diam., 3.2-3.4 times longer than wide, rounded at apex, tepals faintly purplish red; berries globose, pale green, fading to greenish white, finally translucent in lower half; seeds 1-2 per berry.

Eponymy:- The species epithet is from the Latin adjective "annularis" (meaning ring-shaped or arranged in a circle) referring to the ring-shaped swellings at the apex of the nodes.

Distribution:-Anthurium annularum is endemic to Panama, known only from the type locality in the Serranía de Majé.

Habitat and Ecology:-The species grows at $1325 \mathrm{~m}$ in a Premontane rain forest and Tropical wet forest life zones according to the classification proposed by Holdridge et al. (1971). Anthurium annularum is notable because it usually grows in the canopy together with several species of Orchidaceae, at about 25-30 m above the forest floor, in a forest dominated by Quercus Linnaeus (1753b: 994), Sloanea Linnaeus (1753a: 512), Oreomunnea Oersted (1856: 33) and Magnolia Linnaeus (1753a: 535). 
Phenology:-Flowering and fruiting in August. Further investigations are required to determine exact flowering and fruiting seasons.

Conservation status:-The species has a reduced geographic distribution. Its area is strongly impacted by agricultural and livestock activities. We suggest it to be considered in the CR B2ab(iii) category according to the IUCN Red List Criteria (IUCN 2001).

Discussion:-Anthurium annularum is member of section Xialophyllium Schott (1860: 440), by the erect stems that are scandent with long internodes, and with leaf blades typically longer than broad. Within section Xialophyllium, A. annularum could be confused only with A. carnosum Croat \& R.A. Baker (1979: 36) and A. tenerum Engler (1898: 377), all of which have similar blades shape and greenish spadices. Anthurium carnosum also differs in having leaf blades drying black to blue-black, or medium brown, longer petioles, inflorescences with longer peduncles, longer spadices, and infructescences with green tepals and orange berries (Table 1); A. tenerum differing in having conspicuous petiole sheath, longer leaf blades that are grayish when dried, a longer spadix and no ring-shaped internodes (Table 1).

TABLE 1. Characters distinguishing Anthurium annularum from A. carnosum and A. tenerum.

\begin{tabular}{|c|c|c|c|}
\hline & A. annularum & A. carnosum & A. tenerum \\
\hline \multicolumn{4}{|l|}{ Leaves } \\
\hline Blade length & $5-10 \mathrm{~cm}$ & (7) $9-17 \mathrm{~cm}$ & $9-15 \mathrm{~cm}$ \\
\hline Petiole length & $0.9-2.0 \mathrm{~cm}$ & $3-12 \mathrm{~cm}$ & $1-3 \mathrm{~cm}$ \\
\hline Petiole shape & Terete & Weakly sulcate & Terete \\
\hline Petiole sheath length & $0.4-0.5 \mathrm{~cm}$ & $0.7-1 \mathrm{~cm}$ & $1.5-2 \mathrm{~cm}$ \\
\hline Dry color & Yellow-brown & Blue-black to brown & Grayish \\
\hline Primary lateral veins & 16 pairs & 9-13 pairs & 18-19 pairs \\
\hline \multicolumn{4}{|l|}{ Inflorescence } \\
\hline Peduncle length & $1.5-3.5 \mathrm{~cm}$ & $7-13 \mathrm{~cm}$ & $2.5-4 \mathrm{~cm}$ \\
\hline Spadix length & $0.7-1.9 \mathrm{~cm}$ & $3-5.5 \mathrm{~cm}$ & $1.5-3 \mathrm{~cm}$ \\
\hline \multicolumn{4}{|l|}{ Infructescence } \\
\hline Tepal color & Purplish red & Green & Green \\
\hline Berries color & Pale green & Orange & Green \\
\hline
\end{tabular}

In the Lucid Anthurium key A. annularum tracks to A. pulchellum Engler (1885: 273), A. coclense Croat (1981: 321), A. interruptum Sodiro (1902: 301), A. microspadix Schott (1858: 180) and A. stipitatum Bentham (1846: 255). Anthurium pulchellum differs from $A$. annularum in having persistent intact cataphylls, greenish to olive-green drying leaf blades and prominent primary lateral veins on lower surface; $A$. coclense differs from $A$. annularum in having oblong-oblanceolate to elliptic or ovate-elliptic leaf blades, a spadix with ca. 10 flowers visible in the principal spiral, and reddish berries; $A$. interruptum differs from $A$. annularum in having longer internodes $(8-33 \mathrm{~cm})$, brownish green to olive-green drying leaf blades and red berries; $A$. microspadix differs from $A$. annularum in having longer petioles $(5-16 \mathrm{~cm})$, longer peduncles $(5-15 \mathrm{~cm})$ and yellowish-green berries and $A$. stipitatum differs in having reddish-brown drying blades, primary lateral veins prominent on lower surface and prominently stipitate spadix (with $0.5-2.0 \mathrm{~cm}$ long stipe).

\section{Anthurium chucantiense O.Ortiz, Croat \& Baldini, sp. nov. (Figs. 4, 5)}

Anthurium chucantiense is characterized by its epiphytic habit, short stems (ca. $10 \mathrm{~cm}$ long), short internodes at apex of stem, brown cataphylls persisting as fibers at younger nodes only, terete petioles, narrowly oblong-elliptic brownish-drying long-acuminate blades with moderately obscure primary lateral veins, long-pedunculate inflorescences with green spreading-reflexed recurled spathes, a matte greenish to pale orange stipitate spadix and red-orange berries.

Type:-PANAMÁ. Darién: Serranía de Majé, Reserva Privada Chucantí, Cerro Chucantí, sendero hacia los helicópteros, 1325 m, $8^{\circ} 47^{\prime} 45^{\prime}$ N, 78²7’47” W, 29 Aug 2014, Orlando O. Ortiz, Rodolfo Flores, Adriel Sierra, Juvenal Batista, Yessenia Guadalupe, Calixto Rodríguez, Zabdy Samudio \& Zuleika Serracín 2448 (holotype, PMA!; isotypes, FT!, MO!, SCZ!, UCH!).

Epiphytic herb; stems to $10 \mathrm{~cm}$ long; internodes short at the apex of the stem, longer on lower stem, 1-1.5 cm long, 5-10 mm diam.; cataphylls persisting intact at apex, later deciduous with a few remnant fibers at nodes, dark brown, 12.0-17.0 cm long; petioles terete, $8.0-23.0 \mathrm{~cm}$ long, 2-3 mm diam., drying semi-glossy, reddish-brown; blades narrowly oblong-elliptic, $24.5-45.5 \times 3.5-8 \mathrm{~cm}, 5.5-7.4$ times longer than broad, $2-3$ times longer than petioles, 


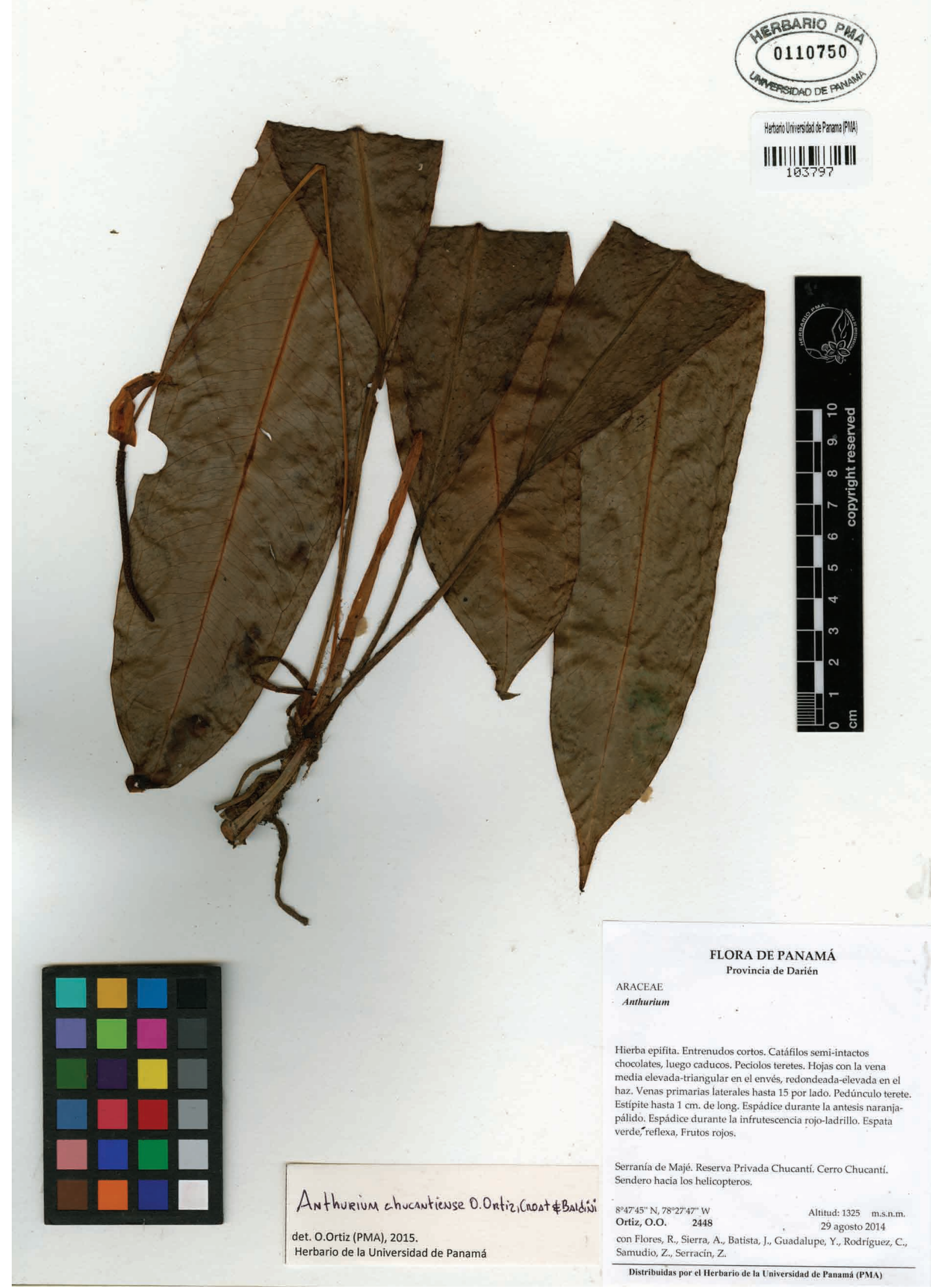

FIGURE 4. Anthurium chucantiense. Holotype specimen: Panamá. Darién: Serranía de Majé, Reserva Privada Chucantí, Cerro Chucantí. Sendero hacia los helicópteros, 1325 m, 847’45” N, 78²7’47” W, 29 Aug 2014, Orlando O. Ortiz, Rodolfo Flores, Adriel Sierra, Juvenal Batista, Yessenia Guadalupe, Calixto Rodríguez, Zabdy Samudio \& Zuleika Serracín 2448 (Photo PMA Herbarium). 

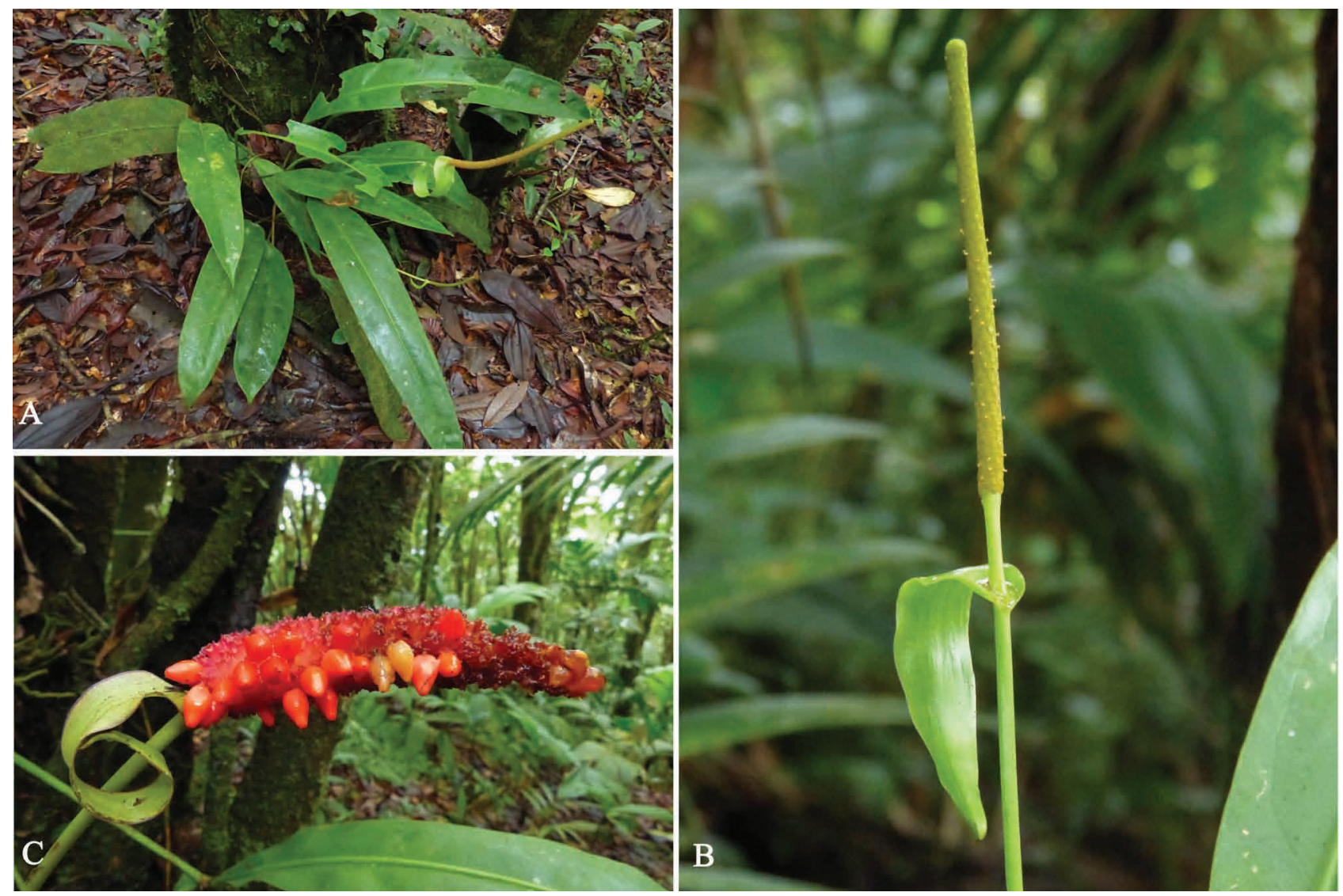

FIGURE 5. Anthurium chucantiense at the type locality. A. In its habitat. B. Flowering spadix. C. Infrutescence spadix (Photo Orlando O. Ortiz).

narrowly long-acuminate at apex, attenuate at base, medium-dark green and semiglossy above, moderately paler and matte below, drying dark brown above, moderately paler and yellow-brown below; midrib prominently raised, narrowly rounded and slightly paler above, V-shaped and paler below, drying concolorous above, reddish-brown below; primary lateral veins up to 15 pairs, arising at $55-75^{\circ}$ angle, obscure and weakly etched above, weakly raised below, concolorous on both surfaces, drying weakly raised and slightly darker below; collective veins arising from one of the lowermost primary lateral veins. Inflorescence erect; peduncle terete, 26.5-54 cm long, $2.0 \mathrm{~mm}$ diam.; spathe green, medium green, decurrent into peduncle $0.2-2.0 \mathrm{~cm}$, linear-lanceolate, $3.0-8.0 \times 1.0-1.9 \mathrm{~cm}$, spreading-reflexed and recurled, abruptly acuminate at apex; spadix erect, cylindrical, $5.7-12.5 \mathrm{~cm}$ long, $2.0-4.0 \mathrm{~mm}$ in diam., yellowish green and matte when stamens begin to emerge, becoming pale orange lower down, stipitate; stipe green, 2-19 mm long, 1-2 mm in diam. when dried; flowers 4 visible in the principal spiral, 3-6 in the alternate spiral; stamens slightly exserted, filaments translucent; anthers yellowish. Infructescence pendent, spathe green with reddish margins, spadix $8.5 \mathrm{~cm}$ long, $1.3 \mathrm{~cm}$ diam., ca. 6.5 times longer than wide, tepals brick-red; berries narrowly ovoid, orange-red, ca. 1 $\mathrm{cm}$ long when fresh, $0.7-0.9 \mathrm{~cm}$ long when dried, bluntly pointed at apex; seeds 2 .

Eponymy:-Anthurium chucantiense is named for the type locality on Cerro Chucantí in the Serranía de Majé of Darién Province in Panama.

Distribution:-Anthurium chucantiense is endemic to Panama, known only from the type locality in the Serranía de Majé.

Habitat and Ecology:- The species grows between 963-1325 m in a Premontane rain forest and Tropical wet forest life zones according to the classification of zones proposed by Holdridge et al. (1971). This species usually grows near the forest floor, 0.2-3 m high, in association with Symbolanthus pulcherrimus Gilg (1896: 344), Hieronyma oblonga (Tulasne 1851: 248) Müller Argoviensis (1865: 66), Calathea spiralis H. Kennedy (1978: 350), Juanulloa wardiana (D'Arcy 1973: 671) S. Knapp (1995: 283) and other Aroid species such: Anthurium tacarcunense and Stenospermation multiovulatum (Engler 1885: 281) N.E. Brown (1894: 684).

Phenology:-The specimens examined are all flowering and fruiting in August and September. Further investigations are required to determine exact flowering and fruiting time. 
Conservation status:- The habitat where A. chucantiense grows is strongly impacted by human activities (farming). This species is restricted to a very small geographic area and for these reasons we consider it in the CR B2ab(iii) category according to the IUCN Red List Criteria (IUCN 2001).

Additional specimens examined (paratypes):-PANAMÁ. Darién: Cerro Chucantí, sendero al filo (helicópteros), bosque premontano, 963 m, 847’25.4” N, 78²7'23.7” W, 18 Sept 2012, Ibáñez, Ayala, Celis \& Peris 8335 AI (MO, PMA).

Discussion:-Anthurium chucantiense had been tentatively placed in section Polyneurium Engler (1898: 384). Within section Polyneurium, A. chucantiense could be confused with A. testaceum Croat \& R.A. Baker (1979: 92) and $A$. cerropirrense Croat (1986: 47), all of which have similar blades shape. Anthurium testaceum differs in having longer stems, leaf blades with conspicuous primary lateral veins on upper surfaces, midrib quadrangular in crosssection on lower surfaces, violet-purple spadix at anthesis and infructescences with violet tepals and oblong-ellipsoid, bright red berries (Table 2); A. cerropirrense Croat differs in having leaf blades with conspicuous and sunken primary lateral veins on upper surfaces, spadix with 7-10 flowers visible in the alternate spiral and purple berries (Table 2).

In the Lucid Anthurium key A. chucantiense tracks to A. carinatum Engler (1885: 275), A. lygrum Croat \& D.C. Bay (in Croat et al. 2006: 40), A. macphersonii Croat \& Oberle (2004: 77) and A. reticulatum Bentham (1846: 255). However, A. carinatum differs from $A$. chucantiense in having $\mathrm{C}$ to $\mathrm{D}$-shaped petioles and purplish to maroon or reddish spadix; A. lygrum differs from $A$. chucantiense in having shorter cataphylls $(6-7.5 \mathrm{~cm})$, sulcate and ribbed petioles and winged peduncles; A. macphersonii differs from $A$. chucantiense in having D-shaped petioles, ovatelanceolate blades with a truncate base and $A$. reticulatum differs from $A$. chucantiense in having sulcate petioles, yellowish to olive-green or grayish drying leaf blades and midrib drying yellowish or grayish below.

TABLE 2. Characters distinguishing Anthurium chucantiense from A. testaceum and A. cerropirrense.

\begin{tabular}{|c|c|c|c|}
\hline & A. chucantiense & A. testaceum & A. cerropirrense \\
\hline \multicolumn{4}{|l|}{ Stems } \\
\hline Internodes length in the basal part of the stem & $1-1.5 \mathrm{~cm}$ & $1.5-2.5 \mathrm{~cm}$ & $0.8-1 \mathrm{~cm}$ \\
\hline Stem length & ca. $10 \mathrm{~cm}$ & ca. $100 \mathrm{~cm}$ & $\geq 20 \mathrm{~cm}$ \\
\hline \multicolumn{4}{|l|}{ Leaves } \\
\hline Primary lateral veins presence & Obscure & Conspicuous & Conspicuous \\
\hline Midrib shape below & Narrowly rounded & Quadrangular & Rounded to acute \\
\hline \multicolumn{4}{|l|}{ Inflorescence } \\
\hline Spadix color & Yellowish to pale orange & Violet-purple & Olive-green \\
\hline Number of flowers in the alternate spiral & $3-6$ & $2-4$ & $7-10$ \\
\hline \multicolumn{4}{|l|}{ Infructescence } \\
\hline Tepal color & Brick-red & Violet & Dark-purple \\
\hline Fruit shape & Narrowly ovoid & Oblong-ellipsoid & Oblong \\
\hline Berries color & Orange-red & Bright red & Purple \\
\hline
\end{tabular}

\section{Acknowledgements}

We offer our gratitude to the Missouri Botanical Garden for funding the Herbarium work through the Alwyn Gentry Fellowship (O.O.O.). We are also very grateful to the curators of the following herbaria: PMA, MO and SCZ for allowing us to access to their collections. We would like to thank Alicia Ibáñez and Rodolfo Flores for providing information about flora and vegetation of Chucantí; Professor Mireya Correa, Director of PMA, botanists and herbarium workers Lucila Guillén and Vielka Murillo (PMA) for providing excellent images of the holotypes and Dr. Carlos Ramos, Dean of the Faculty of Natural Sciences and Technology, for providing facilities and other support. Special thanks go to Dr. Peter C. Boyce and Dr. Alberto Sidney Taylor Blake for their revisions and suggestions.

\section{References}

ANCON (Asociación Nacional para la Conservación de la Naturaleza) (2010) Plan de Conservación para el Sitio Darién. Available from: http://www.naturapanama.org/index.php/descargas/documentos/category/12-fondo-darien?download=51:plan-de-conservacionpara-el-sitio-darien (accessed 20 December 2015) 
Batista, A., Köhler, G., Mebert, K. \& Vesely, M. (2014) A new species of Bolitoglossa (Amphibia: Plethodontidae) from eastern Panama, with comments on other members of the adspersa species group from eastern Panama. Mesoamerican Herpetology 1: 97-121.

Bentham, G. (1846) Plantarum Hartwegianarum. Sectio Altera. In: Bentham, G. (Ed.) Plantas Hartwegianas: imprimis mexicanas adjectis nonnullis Grahamianis enumerat novasque /describit Georgius Bentham. Pamplin, London, pp. 113-266. http://dx.doi.org/10.5962/bhl.title.437

Bezark, L.G., Tyson, W.E. \& Schiff, N.M. (2013) New species of Cerambycidae from Panama, with new distribution records (Coleoptera: Cerambycidae). Zootaxa 3608 (4): 273-277.

http://dx.doi.org/10.11646/zootaxa.3608.4.5

Boyce, P.C. \& Croat, T.B. (2012) The Überlist of Araceae: Totals for published and estimated number of species in aroid genera. Available from: http://www.aroid.org/genera/120110uberlist.pdf (accessed 10 November 2015)

Brown, N.E. (1894) New or Noteworthy Plants. The Gardeners'Chronicle: a weekly illustrated journal of horticulture and allied subjects. ser. 3 15: 684-685.

Correa, A.M.D., Galdames, C. \& De Stapf, M.S. (2004) Catálogo de las Plantas Vasculares de Panamá. Quebecor World Bogotá, Colombia, 600 pp.

Croat, T.B. (1981) Studies in Araceae III: New species of Anthurium from Central America. Selbyana 5: 315-341.

Croat, T.B. (1986) A Revision of Genus Anthurium (Araceae) of Mexico and Central America. Part II: Panama. Monographs in systematic botany from the Missouri Botanical Garden 14: 1-204.

Croat, T.B. (1997) A revision of Philodendron subgenus Philodendron (Araceae) for Mexico and Central America. Annals of the Missouri Botanical Garden 84: 311-704.

http://dx.doi.org/10.2307/2992022

Croat, T.B. \& Baker, R.A. (1979) The genus Anthurium (Araceae) in Costa Rica. Brenesia 16 (Suppl. I): 1-174.

Croat, T.B. \& Bunting, G.S. (1979) Standardization of Anthurium descriptions. Aroideana 2: 15-25.

Croat, T.B. \& Oberle, B. (2004) New species of Araceae from Colombia. Aroideana 27: 64-89.

Croat, T.B., Bay, D.C. \& Yates, E.D. (2006) New Taxa of Anthurium (Araceae) from the Bajo Calima Region, (Valle, Chocó) Colombia and Ecuador. Novon 16: 21-51. http://dx.doi.org/10.3417/1055-3177(2006)16[25:NTOAAF]2.0.CO;2

D’Arcy, W.G. (1973) Flora of Panama, Part IX. Family 170. Solanaceae. Annals of the Missouri Botanical Garden 60: 573-780. http://dx.doi.org/10.2307/2395139

Dinerstein, E., Olson, D.M., Graham, D.J., Webster, A.L., Primm, S.A., Bookbinder, M.P. \& Ledec, G. (1995) A Conservation Assessment of the Terrestrial Ecoregions of Latin America and the Caribbean. World Wildlife Fund-US, The World Bank, Washington, DC, 129 pp.

http://dx.doi.org/10.1596/0-8213-3295-3

Dressler, R.L. (2003) Chysis violacea, una especie nueva y llamativa de Panamá oriental, con el pronóstico de otra aún no descrita. Orquideología 22: 237-243.

Engler, A. (1885) Beiträge zur Kenntnis der Araceae. VI. 13. Araceae Lehmannianae. Botanische Jahrbücher für Systematik, Pflanzengeschichte und Pflanzengeographie 6: 273-285.

Engler, A. (1898) Beiträge zur Kenntnis der Araceae. VIII. 15. Revision der Gattung Anthurium Schott. Botanische Jahrbücher für Systematik, Pflanzengeschichte und Pflanzengeographie 25: 351-476.

Fund, W. (2014) Eastern Panamanian montane forests. Available from: http://www.eoearth.org/view/article/151914 (accessed 20 December 2015)

Gilg,E.(1896)Beiträge zur Kenntnis der Gentianaceae.I. Botanische Jahrbücherfür Systematik, Pflanzengeschichte und Pflanzengeographie 22: 301-347.

Grayum, M.H. (1986) New Taxa of Caladium, Chlorospatha, and Xanthosoma (Araceae: Colocasioideae) from Southern Central America and Northwestern Colombia. Annals of the Missouri Botanical Garden 73: 462-474. http://dx.doi.org/10.2307/2399124

Haigh, A., Mayo, S.J., Croat, T.B., Reynolds, L., Mora Pinto, M., Boyce, P.C., Lay, L., Bogner, J., Clark, B., Kostelac, C.V. \& Hay, A. (2009) Interactive web-taxonomy for the Araceae: www.cate-araceae.org. Blumea 54: 13-15.

http://dx.doi.org/10.3767/000651909X474032

Holdridge, L.R, Grenke, W.C., Hatheway, W.H., Liang, T. \& Tosi, J.A. (1971) Forest Environments in Tropical Life Zones: a pilot study. Pergamon Press, New York, 747 pp.

Kennedy, H. (1978) Calathea elegans and C. spiralis - new Panamanian Marantaceae. Botaniska Notiser 131: 349-354.

Knapp, S.D. (1995) New taxa and combinations in the tribe Juanulloeae (Solanaceae). Novon 5: 281-283.

http://dx.doi.org/10.2307/3392266

Laurance, W.F. (2008) Adopt a Forest. Biotropica 40: 3-6. 
http://dx.doi.org/10.1111/j.1744-7429.2007.00391.x

Linnaeus, C. (1753a) Species Plantarum 1. Holmiae: Impensis Laurentii Salvii, Stockholm, 560 pp.

http://dx.doi.org/10.5962/bhl.title.669

Linnaeus, C. (1753b) Species Plantarum 2. Holmiae: Impensis Laurentii Salvii, Stockholm, 1200 pp.

http://dx.doi.org/10.5962/bhl.title.669

Miranda, R.J. \& Bermúdez, S.E. (2010) Strophaeus sebastiani, nueva especie de Barychelidae (Araneae: Mygalomorphae) de Panamá. Boletín de la Sociedad Entomológica Aragonesa 47: 175-179.

Müller Argoviensis, J. (1865) Euphorbiaceae. Vorläufige Mittheilungen aus dem für DeCandolle's Prodromus bestimmten Manuscript über diese Familie. Linnaea 34: 1-224.

Oersted, A.S. (1856) Plantae novae centroamericanae. Videnskabelige Meddelelser fra Dansk Naturhistorisk Forening i Kjøbenhavn 3: 33-43.

Schott, H.W. (1829) Für Liebhaber der Botanik. Wiener Zeitschrift für Kunst, Literatur, Theater und Mode 94: 779-780.

Schott, H.W. (1858) Ueber Aroideen Central-America's. Oesterreichische Botanische Zeitschrift 8: 177-182. http://dx.doi.org/10.1007/BF02106075

Schott, H.W. (1860) Prodromus Systematis Aroidearum. Vindobonae Typis congregationis Mechitharisticae, Vienna, 602 pp. http://dx.doi.org/10.5962/bhl.title.68

Sodiro, L. (1902) Anturios Ecuatorianos (Gen. Anthurium Schott. Ord. Aroideas). Anales de la Universidad Central del Ecuador 15: 291-306.

Tulasne, L.R. (1851) Antisdesmata et Stilaginellas, Novum Plantarum Genus, Recenset Nonnullaque De Eis Affinibus. Annales des Sciences Naturelles, Botanique, série 3 15: 180-266. 